Eskişehir Osmangazi Üniversitesi iißBF Dergisi

Aralık 2020, C. 15, S. 3, $1061-1080$

Başvuru : : 17.10.2019

Kabul : :06.04.2020

\title{
Seçilmiş Ülkeler Kapsamında Mükellef Haklarının Değerlendirilmesi ${ }^{1}$
}

Engin Hepaksaz ${ }^{2}$

Orçun Avcl ${ }^{3}$

Seçilmiş Ülkeler Kapsamında Mükellef Haklarının Değerlendirilmesi

Öz

Günümüzde mükellef hakları konusu mükellef odaklı vergileme anlayışının bir sonucu olarak, açık bir şekilde ülkelerin gündemine alınmaya başlanmıştır. Özellikle de gelişmiş ülkeler bağlamında mükellef hakları konusunda birçok yasal düzenleme yapıldığı görülmektedir. Bu hakların insan hakları ile yakın bir ilişki içinde olduğu söylenebilir. Bazı ülkeler bildirge ile düzenleme yaparken bazı ülkelerin ise, ilgili vergi kanunlarında mükellef haklarını düzenlediği görülmektedir. Diğer bazı ülkelerde ise, karma bir yapı gözlemlenmektedir. Günümüzde, dünyada mükellef hakları konusunda yeni bir eğilim olduğu söylenebilir. Bu bağlamda çalışmada, mükellef haklarının kuramsal yapısı hakkında bilgi verilerek seçilmiş ülkeler kapsamında mükellef haklarının gelişim süreci ve mevzuat boyutu inceleme konusu yapılmaktadır.

Anahtar Kelimeler: Mükellef Hakları, Mükellef Hakları Bildirgeleri, Seçilmiş Ülkeler.
Evaluations about the Taxpayer Rights in the context of the Selected Countries

Abstract

Nowadays the subject of the rights of taxpayers have initiated to be put on countries agenda in an open manner as a result of the taxpayer-oriented sense of taxation. Especially within the context of developed countries, it is observed that many legal arrangements have been made on the rights of taxpayers. It can be said that these rights have close relationships with human rights. While some countries regulate them by charter, some countries regulate taxpayer rights via the relevant tax laws. In some other countries, a mixed structure is observed. Today it can be said that there is a new trend about the subject of the rights of taxpayers around the world. In this context, the process of development of taxpayer rights and the legislative dimension within the scope of selected countries are examined by giving information about the theoretical structure of taxpayer rights.

Keywords: Taxpayers' Rights, Taxpayer Rights Charters, Selected Countries.

\section{Giriş}

Gelir idarelerinde yaşanan modernizasyon ile birlikte mükellef hakları konusunda gelişmiş ve gelişmekte olan birçok ülkede çeşitli çalışmalar yapılmaktadır. Bununla birlikte mükelleflere olan bakış açısında da ciddi değişimler meydana gelmiştir. Artık birçok ülke, "mükellefle birlikte" anlayışıyla hareket ederek vergi idaresindeki çalışmalarını yeni düzene göre şekillendirmektedir. Bilgi ve iletişim çağının beraberinde getirdiği pozitif katkıların vergileme alanına da sirayet ettiği göz önüne alındığında, gelişmiş ülkeler tarafından mükellef hakları konusunda yapılan çaıışmaların birçok dünya ülkesine örnek olacağı göz ardı edilemeyecektir. Bu konudaki bir diğer faktör olarak, mükelleflerin geçmişe oranla vergi bilincinin ve vergi konusundaki donanımının daha izlenebilir hale geldiğini söyleyebilmek mümkündür. Dolayısıyla tüm bu yaşananların mükellefler lehine yansımalarından da bahsedilebilecektir. Çalışmada Kıta Avrupası ve Anglosakson

\footnotetext{
${ }^{1}$ Bu çalışma, İzmir Kâtip Çelebi Üniversitesi Bilimsel Araştırma Proje Birimi (BAP) tarafından 2017-TDR-SOBE-0034 proje koduyla desteklenen, proje yürütücülüğünü ve tez danışmanlığını Prof. Dr. Engin Hepaksaz'ın yaptığı “Türkiye'de ve Seçilmiş Ülkelerde Vergi İnceleme Sürecinde Mükelleflerin Hak ve Ödevleri” başlıklı doktora tezinden türetilmiştir.

2 Prof. Dr., İzmir Kâtip Çelebi Üniversitesi iiBF, Maliye Bölümü. engin.hepaksaz@ikc.edu.tr, Yazar ORCID bilgisi: https://orcid.org/0000-0003-4383-4091.

3 Dr. Öğr. Üyesi, Aksaray Üniversitesi IiBF, Maliye Bölümü. orcun.avci@outlook.com, Yazar ORCID bilgisi: https://orcid.org/0000-0002-7917-9802.
} 
hukuk anlayışına mensup seçilmiş bazı ülkelerde mükellef hakları konusunda yaşanan gelişmeler ele alınmakta ve gelinilen nokta üzerinden mükellef haklarına ilişkin değerlendirmeler ve bazı çözüm önerileri üzerinde durulmaktadır.

\section{Mükellef Haklarının Kuramsal Yapısı}

Mükellef hakları ile ilgili genel kabul görmüş bir tanımlama yoktur. Ancak mükellefin korunması ve 'mükellef odakı' vergi hukuku ilişkisi anlayışının gelişmesiyle birlikte konu önem kazanmış ve bu kavrama ilişkin bir tanımlama gereksinimi ortaya çıkmıştır. Bu anlamda örneğin; mükellefin korunması kavramının, "vergi otoriteleri tarafından vergi toplamaya karşı vergi mükelleflerini korumak amacıyla yazılı veya yazısız kurallar" şeklindeki tanımının ötesine geçilerek mükellef odaklı vergi anlayışının temel unsurları üzerinde tartışma gereği önem arz etmektedir. Nitekim bu konuda mali ve mali olmayan yönlerin de bir bütünlük teşkil ettiği hususunun göz ardı edilmemesi gerekmektedir (Çetin ve Gökbunar, 2010: 25).

Günümüzde mükellef hakları, özgürlüklerin üzerine kurulmuş sistemin kilit konusunu teşkil etmektedir (Tieghi, 2015: 1). Mükellef haklarının korunması hususunun hem bireysel hem de sosyal yönleri bulunmaktadır. Bireysel açıdan mükellefin yükümlülüklerinin tam olarak tanımlanmasını sağlamakla beraber vergi idaresinin eylemlerinin doğruluğunun saptanması ve meydana gelen hataların giderilmesi hususu da ön plana çıkmaktadır. Sosyal açıdan ise, mükelleflerin çeşitli hukuki araç ve koşulları kullanma yeteneği ve bunların bireyin haklarına saygılı bir biçimde yürütülmesi inancı gündeme gelmektedir. Her iki husus birlikte sağlanabildiğinde devlet ile bireyler arasındaki bağlılık duygusunda ve vergi kanunlarına uyum gücünde artış sağlanabileceği savı tartışmaya açık hale gelebilecektir. Bu yönüyle mükellef hakları, birey ile kamu idaresi arasında arzu edilen ilişkilerin ortaya çıkmasının sağlanmasında günümüz medeniyetinin bir başarısı olarak kabul edilebilir (Brzezinski, 2009: 31-32).

Geçmişten günümüze kadar gelinen süreçte, mükellef hakları konusunun bir dizi süreçten geçmiş ve geçmekte olduğu söylenebilir. Birinci süreçte, modern vergi sisteminin korunması ve tanımlanması sağlanmıştır. Bu aşamada; vergi kararlarının gözden geçirilmesi, vergi toplama ve ödenmesindeki bazı temel haklar tesis edilmiştir. İkinci süreçte, mükellefler ve gelir idaresi arasındaki kapsamlı etkileşimi yönetmek için bir kanuni ve idari çerçevenin geliştirilmesi hedeflenmiştir. Bu kapsamda verginin mahremiyeti, gizliliği, erişim kapsamının iyileştirilmesi, arama hükümleri ve idari süreci kolaylaştıracak bir dizi hakların sağlanması gibi konulara ilişkin özel, maddi ve manevi birtakım haklar ön plana çıkmıştır. Üçüncü süreçte ise, doğrudan yabancı yatırım ve ticaretin geliştirilmesi için bir vergi çerçevesinin oluşturulması ve gönüllü uyumu arttırmak için mükellef haklarının açıkça ifade edilmesi gündeme gelmiştir. Burada haklar, mükellef ile gelir idaresi arasındaki ilişkilerin ve şeffafığın geliştirilmesine odaklanmaktadır. Bu süreçte yapısal bir vergi reformu kapsamında hem yerli mükellefler hem de yabancı yatırımcılar açısından net bir çerçevenin çizilmesi hedeflenmiştir. Son süreç ise, anlaşmalar ve ticari bloklar yoluyla uluslar üstü korumanın arttırılmasına yöneliktir. Bunun esas etkisi genellikle dolaylı olmakla birlikte zamanla yurtiçi korumanın gelişimini etkileyeceği hususu tartışılmaktadır (Bentley, 2002).

Mükelleflerin korunması, korunacak haklara ve korumayı sağlamak için kullanılan uygulama yöntemine göre değişebilmektedir. Genellikle uygulama yöntemleri, bir toplumun korumaya ihtiyaç duyduğu haklardan çıkmaktadır. Bu konuda akla ilk gelen soru, hangi hakların korunacak olmasıdır. Korunacak haklarla ilgili liste oldukça uzun olmakla birlikte, basitlik için daha sonra farklı sınıflara ayrılabilecek olan iki ana hak türünü tanımlamak mümkündür. İlk hak türü, tahsilat ve icra sürecinin günlük işleyişinde adalet ve verimlilik görmek isteyen mükelleflerin genel 
haklarını kapsamaktadır. İkinci tür haklar, vergi kanunlarının uygulanması ve işleyişi ile ilgili hakları kapsamaktadır. Bu tür haklar, vergi kanunları ile mükellefler arasında ortaya çıkmakta, kanunlar tarafından yürürlüğe konulmakta ve kanunun özünün temel işleyişine odaklanmaktadırlar (Bentley, 2007: 107-108).

Mükellef haklarının farklı kaynak ve türleri (örneğin genel ve özel haklar ayrımında olduğu gibi) ile bunların yasal karakterindeki farklılıklar ve uygulama ölçüleri dikkate alındığında, bu hakların birbirleriyle olan ilişki ve etkileşimi ile belirli ölçüde sistemin kendi özelliklerinden kaynaklanan hususların birlikte düşünülüp değerlendirilmesi gerekliliği ortaya çıkmaktadır (Brzezinski, 2009: 25). Bu açıklamalar ışığında mükellef haklarının hukuki dayanağı; anayasa, kanunlar, uluslararası anlaşmalar, mükellef hakları bildirgeleri ve vergi idaresinden doğan kaynaklar şeklinde sınıflandırılabilir. Mükellef hakları konusunda ülkelerin daha çok "Mükellef Hakları Bildirgesi" ile düzenleme yoluna gittikleri görülmektedir. Ancak vergi kanunlarının içerisinde kanuni bir metin şeklinde düzenleme yapıldığı da gözlemlenmektedir. İster kanuni düzenleme olarak ister idarelerin tek tarafı niyet beyanı olarak yayımlanmış olsun, bu bildirgeler bir yandan mükellef haklarını sıralarken öte yandan ilgili idarenin bunları koruma noktasındaki yükümlülüklerini de hatırlatan temel özelliğe sahiptir (Abanoz, 2014). Mükellef hakları bildirgeleri, mükelleflerin vergileme ile ilgili olan ilişkilerindeki haklarını açıkça özetlemek ve bu bilgileri mükelleflere erişilebilir hale getirmeyi hedeflemektir. Çoğu mükellef hakları bildirgesi, kendi başına hukuki bir belge olmadığı için kanun rehberi niteliği kapsamından öteye gidememektedir (OECD, 2003: 6).

Bu bilgiler ışığında aşağıda seçilmiş bazı ülkelerde mükellef haklarına ilişkin gelişim süreci ve mevzuat boyutu ele alınıp değerlendirilmeye çalışılmıştır. Ülke uygulamalarında birbirine benzer gelişmeler yaşanmakla birlikte, mükellef haklarının yasal mevzuat içerisinde oturduğu yer konusunda çeşitli nedenlerle farklı anlayışlar ortaya çıkabildiği dikkat çekmektedir.

\section{Seçilmiş Ülkelerde Mükellef Hakları}

Mükellef hakları kavramı özellikle gelişmiş demokratik ülkelerde önemli bir yer işgal etmektedir. Bu bakımdan Türkiye'de mükellef haklarının geldiği nokta kapsamında, ileride yapılacak karşılaştırmalı çalışmalara fikir vermesi açısından bu ülkelerin ele alınması önem arz etmektedir. Bu çalışmada mükellef hakları konusu Kıta Avrupası veya Anglosakson hukuk sistemine bağlı olan önde gelen gelişmiş demokratik ülkeler örnek alınarak değerlendirmeye tabi tutulmaya çalışılmıştır.

\subsection{Kıta Avrupası Hukuk Sistemi}

Kıta Avrupası hukuk sistemi, kaynağını büyük ölçüde Roma Hukuku’ndan almaktadır. Bu hukuk sisteminin başlıca özelliği kuralların büyük ölçüde yazılı olmasıdır. Bu sistemde hukukun biçimsel kaynakları esas itibariyle anayasa, kanun ve yönetmelik gibi yazılı kurallardan oluşmaktadır. Örf ve adet, bu hukuk sisteminde hukukun tamamlayıc kaynağı pozisyonundadır. Bu sistemde içtihat, hukukun yardımcı kaynağı olarak kabul görmektedir. Kural olarak, bir mahkemenin kararı kendisini ve bir üst mahkemenin kararı alt mahkemeyi bağlamaz. Başka bir deyişle belli bir olayda belli bir kararı veren mahkeme, benzer bir olayda tamamen başka bir karar verebilir. Keza; bir alt mahkeme belli olayda, üst mahkemenin aynı olayda verdiği kararı izlemeyebilir (Gözler, 2009: 130).

Hukuk, özel hukuk ve kamu hukuku olarak iki ana gruba ayrılmaktadır. En önemli konulardan birisi ise, yargı ayrılı̆ının olması konusudur. Adli ve idari yargı olmak üzere iki ayrı düzen vardır. İdari yargı genelde kamu hukuku alanında, adli yargı ise genelde özel hukuk ve ceza hukuku 
alanında yetkilidir (Anayurt, 2018: 141). Çalışmada Kıta Avrupası hukuk sistemini benimseyen ülkeler olarak; Fransa, Almanya değerlendirilmiştir. Bunlara ek olarak esas itibariyle Kıta Avrupası hukuk sistemini benimsemekle beraber Anglosakson hukukun etkisinin az da olsa görüldüğü Japonya ayrı bir örnek olarak ele alınmıştır.

\subsubsection{Fransa}

Fransa'da vergilendirme işlemlerinden sorumlu genel birim Vergiler Genel Idaresi'dir. Ekonomi ve Maliye Bakanlı̆̆ı'na (Ministére des Finances et des Comptes Publics) bağlı bir bölüm olan Vergiler Genel İdaresi'nin temel amacı, vergi gelirlerini güvence altına almak ve aynı zamanda vergi gelirlerini en üst düzeye çıkarmaktır (Organ, 2008: 73). Fransa'da dünyadaki gelir idarelerinin yapılandırılmalarına paralel bir şekilde modernizasyon çalışmaları 2000 yılında başlamıştır. Modernizasyon için sistemde sadeleştirme, şeffaflık, yeni teknoloji kullanımı, diyalog ve deneyim gibi konularda çalışmalar gerçekleştirilmiştir. Kamu kurumlarında mükelleflere yardım amaçlı gerçek kişiler için "Mükellef Temsilcisi" birimi oluşturulmuş, şirketlerin vergisel işlemlerini kolaylaştırma amaçlı ise, "Büyük Iş̧letmeler Yönetim Birimi" kurulmuştur. Uyuşmazlık konusunda ise çözümlerin hız kazanması için "Danışma ve itiraz Merkezi", mükelleflere yardım sağlamak için "Eğitim ve Araştırma Merkezi", kamu hizmetlerinde şeffaflık ve etkinlik için "Kamu Hizmetleri Evi"nin kurulması da diğer çalışmalar arasında yer almaktadır (Vanistendael, 1996: 15; Gerçek vd., 2015: 39).

Fransız vergi hukukunda, idarenin denetim ve düzeltme yetkisinin yanı sıra mükelleflerin sahip oldukları birtakım haklar ve bunlara ilişkin koruyucu düzenlemeler mevcuttur. Koruyucu düzenlemelerin kaynağı, Türk hukukuna benzer şekilde; anayasa, yasalar, idari düzenleyici işlemler ve mahkeme kararlarıdır. Yargı kararları bu hususta oldukça önem arz etmektedir. 2008 yılında Bütçe, Kamu Hizmeti ve Kamu Hesabı Bakanlığı'nın hazırlatmış olduğu “idare ile Mükelleflerin Iliş̧kilerinin Hukuki Güvenliğinin Geliştirilmesi Raporu"nda da bu durum açıkça ifade edilmiştir. İlgili raporda özellikle üç alanda alınacak tedbirlerle mükelleflerin daha iyi koruma altında olacağından bahsedilmiştir. Söz konusu raporda (Karataş Durmuş, 2015: 111):

$>$ "Hukuk normlarının yapılması esnasında ve idarenin bu normları uygularken dikkat etmesi gereken hususların neler olduğu,

$>$ Bu normların uygulanmasının pratikteki şekillerinin nasıl olduğu yani idare mükellef ilişkilerinin şekli,

> Vergi yargılama sürecinin uzunluğundan bahsedilmiştir".

Fransa'da mükelleflerin korunması ve idare ile ilişkilerinin nasıl şekillenmesi gerektiğini belirleyebilmek amacıyla hem yasama (Fransız Vergi Usul Kanunu, LPF art.L10 ve devamı) hem de yürütme organının farklı düzenlemeleri bulunmaktadır. Mükelleflerin korunmalarına vergi incelemesi açısından baktığımızda hangi tür vergi incelemesi yapılırsa yapılsın mükelleflerin sahip olduğu birtakım haklar ve koruyucu tedbirlerin söz konusu olduğu görülmektedir. Tüm bunlar göz önünde bulundurularak mükellefler ile vergi idaresi arasındaki ilişkiler hususunda Eylül 2005 tarihinde Fransız vergi idaresinde köklü bir değişiklik yapılmış ve "Mükellef Bildirgesi" (La Charte du Contribuable) yayımlanmıştır. Verginin tahsilinin kolaylaştırılması ve hem idarenin hem de mükelleflerin sorumlulukları ve hakları hakkında bilgiler içeren bir bildirgedir (Karataş Durmuş, 2015: 126).

Bildirge incelendiğinde, mükellef haklarının gelişiminde gelir idaresinin mükellef odaklı yaklaşımı öne çıkmaktadır (Direction Générale des Finances Publiques, 2018: 4). Bu bildirge kapsamında açıklanan konular (Karataş Durmuş, 2016: 112-113): 
> "Vergi idaresinin hayatı kolaylaştırmaya yönelik hizmetleri,

$>$ Mükelleflerin ödevleri,

$>$ idarenin mükelleflere saygı duyduğu ve onların haklarını kabul ettiği,

$>$ iyi niyet karinesi,

$>$ Denetim sürecinde mükelleflerin denetim elemanları ile birlikte birtakım ödevleri; denetim esnasında mükelleflerin neler yapması gerektiği, aksi davranış/arın hangi sonuçları doğurabileceği; mükellefin hatası veya kaçakçılığı gibi bir durum tespit edilirse ne gibi sonuçlarla karşılaşılacağı,

$>$ idarenin adil davrandığı ve bu kapsamda;

- Alanında profesyonel olduğu,

- Mükellefe karşı tarafsız ve gerçekçi davrandığı,

- Mükellef ile ilişkisinde dengeyi araştırdığı,

- Şeffaf olduğu.

$>$ Mükellefin sadık olması ve bundan kastedilenin ise;

- Vergi beyanının doğru ve tam olması,

- Idarenin bilgi taleplerine karşı açık, net, tam ve zamanında cevap verilmesi,

- Durumları ne ise onu bildirmeleridir".

Fransız mükellef hakları bildirgesi, iki taraflı bir nitelik taşımaktadır. İdarenin ödevleri ve neler yapacağı belirtilmesine karşılık, idare ile mükelleflerin ilişkilerindeki usul kuralları ve mükelleflerin neler yapması gerektiği, hangi haklarının var olduğu ve inceleme süreci hakkında da bilgiler içermektedir. Bu sebeple de Fransız mükellef hakları bildirgesi için daha kapsamlı ve detaylı bir belge diyebiliriz. Bu bildirge haricinde özellikle vergi denetimine tabi mükelleflerin haklarının ve korunmalarının sağlanması için düzenlenmiş başka bir bildirge daha bulunmaktadır. Bu bildirge ise 1987 yılında, "Kontrol Edilen Mükelleflerin Hakları ve Ödevleri Bildirgesi" (La Charte des Droits et Obligations du Contribuable Vérifié) isimli çıkarılan bildirgedir. (Karataş Durmuş, 2015: 127-128).

Bildirge 2018 yılında yeniden güncellenmiş ve söz konusu bildirgede mükellef haklarının korunması, söz konusu kanunların adil bir şekilde uygulanmasından idarenin sorumlu olduğu ve idarenin işlemlerine karşı yargı yolunun açık olduğu belirtilmiştir (Direction Générale des Finances Publiques, 2018: 3).

\subsubsection{Almanya}

Alman vergi hukukunda mükellefler ile vergi idaresi arasındaki ilişki dayanışma esasına göre kurulmuştur. Mükelleflerin birçok konuda söz hakkının bulunduğu ve vergilemede etkin bir rol aldığı söylenebilir.

Almanya'da mükellef haklarının korunması ile ilgili temel dayanaklar, Alman Anayasası ve uluslararası hukuk kaynaklarıdır. Uluslararası hukuk kaynakları, Almanya'nın üyesi olduğu Avrupa Birliği Hukuku'ndan ve taraf olduğu çifte vergilendirmeyi önleme anlaşmalarından kaynaklanmaktadır. Birçok ülkenin aksine, Alman Anayasası'nda mükellef hakları konusunda çok sayıda hak mevcuttur. Bunlar; eşitlik ilkesi, özel hayatın korunması, mülkiyet hakkı, dava açma

\footnotetext{
${ }^{4}$ Bildirge hakkında ayrıntılı bilgi için bakınız: https://www.economie.gouv.fr/files/files/directions_services/dgfip/controle_fiscal/organisation_fonctionnement/charte_aout_2018.pdf, (Erişim: 10.10.2019).
} 
hakkı olarak sayılabilir. İdareye karşı mükellefin haklarını koruyan anayasal garantileri ikiye ayırmak mümkündür. Bunlar eyaletlerin yasama gücünün kötüye kullanılmasını önlemeye yönelik ve idari birimlerin mükelleflere karşı davranışlarına yönelik düzenlemelerdir (Gerçek vd., 2015: 41).

Alman vergi hukukuna göre mükellef hakları kapsamında (Kaya vd., 2017: 179-180) ön plana çıkan haklar; mükellefin dinlenilme hakkı ${ }^{5}$, mükellefin kendisi ile ilgili bilgilere ulaşma hakkı ${ }^{6}$, dilekçe hakkı ${ }^{7}$, vergi mahremiyeti hakkı ${ }^{8}$, yardım alma hakkı ${ }^{9}$ gibi haklardır. Almanya'da mükellefler bir vergi uzmanından (genellikle işletme veya ekonomi alanında lisans derecesi olan) veya bir avukattan ya da güvendiği başka bir kişiden yardım alma hakkına sahiptir. Bu durum, temsilci kullanma hakkını ifade etmektedir (Reimer, 2009: 207). Mükelleflere ilişkin bilgilerin gizliliği konusuna baktığımızda, tam bir anayasal hak olarak görülmediği dikkatimizi çekmektedir. Ancak anayasal hakları koruyucu bir araç olarak görülmesi hasebiyle dolaylı yoldan anayasal koruma sağlamaktadır. Özellikle Alman Anayasası'nın 14. maddesi mülkiyetin anayasal olarak korunması, iş ve ticari sırlarından güvence altına alınması ile yakından ilişkilidir. Mükelleflere ilişkin bilgilerin gizliliği konusu vergileme sürecinde, yargılama sürecinde, ceza ile ilgili işlemler sırasında veya vergi yetkililerinin bilgi toplamaları esnasında görevleri sebebiyle öğrenmiş oldukları başkaları ile ilgili bilgileri de içermektedir. Ayrıca mükelleflerin ticari işleri ile ilgili sırları da bu kapsamda değerlendirilmektedir (Gökbel, 2000: 111).

\subsubsection{Japonya}

Japonya (National Tax Agency, NTA) mükellef haklarına önem veren bir ülkedir. Hem sosyal hem de idari yapılar ve vergi sisteminin yapısı, konunun gündeme getirilmesine ve dikkat çekilmesine neden olmuştur. Vergi otoritelerinin genel olarak vergi sistemindeki aşırı baskın uygulamaları, zaman zaman sınırsız takdir yetkisine ve haksız, şeffaf olmayan vergi uygulamalarına yol açmıştır. Böylelikle mükelleflerin haklarını, vergi makamlarından ziyade mükellefler açısından adil, şeffaf bir idare ile güvence altına almak ve korumak, ülkede uzun süredir gündemi işgal etmiş ve etmeye devam etmektedir (Yurtsever, 2010: 337-338).

Japonya'da mükellef haklarıyla ilgili gelir idaresinin bünyesinde mükellef şikâyetlerini değerlendirme ve çözüme kavuşturmak için, diğer birçok gelişmiş ülkelerde olduğu gibi bir sistem geliştirmiştir. Bu anlamda Japonya'da mükellef ile gelir idaresi ilişkisini düzenleyen “vergi mükellefi destek birimi" (Taxpayer Support) Temmuz 2001'den bu yana hizmet vermektedir. Ayrı bir kanuni düzenlemeyle kurulan bu birim, gelir idaresine bağlı olarak karşılaşılan sistematik

\footnotetext{
${ }^{5}$ Bu hakka göre, mükellef hakkında işlem yapılmadan önce mükellefe kendini ifade etme hakkı verilmiştir (Alman Vergi Usul Kanunu , “AO” m. 91).

${ }^{6}$ Mükellef kendisi ile ilgili yapılacak işleme ve bu işlemin gerekçesine ulaşma hakkına sahiptir (AO m. 91). Mükelleflerin bu haklarını kullanırken ortaya çıkan masraflar bu hakkın kullanımını sınırlandırmaz.

${ }^{7}$ Mükellef kendisi ile ilgili yapılan veya yapılacak işlemlere karşı dilekçe ile dahil olma hakkı, Alman Anayasa'sı tarafından tanınmıştır. Buna göre; "herkes tek başına veya başkalarıla birlikte toplu olarak, yetkili makamlara veya yasama meclislerine, yazılı olarak dilek ve şikâyette bulunma hakkına sahiptir". Federal Almanya Cumhuriyeti Anayasası 17. madde, http://www.adalet.gov.tr/duyurular/2011/eylul/anayasalar/ulkeana/pdf/08-ALMANYA\%20209-276.pdf, (Erişim: 21.07.2018).

${ }^{8}$ AO'ya göre, mükelleflerin kendisi ile ilgili gizli tutulması gereken bilgilerin açığa çıkartılmaması hakkı söz konusudur. Türkiye'de olduğu gibi AO'da da bunun istisnaları bulunmaktadır. Kamu yararının olduğu durumlarda Alman kurumları mükellef bilgilerini yayımlayabilmektedir. Mahkemelerde görevli olanlar, vergi ile ilgili işlerde görevlendirilenler ve kilise ofisleri bu mahremiyete uymak zorundadır.

${ }^{9}$ Mükellefler için kanunlar, yönetmelikler ve uygulamalar oldukça karışık olabilir bu sebeple mükellefler kendileri ile ilgili yapılacak işlemlerin her safhasında danışmanlardan yardım alabilirler, isterlerse yetkili temsilci olarak da atayabilirler (AO m. 80).
} 
sorunlara ilişkin raporlama gerçekleştirmektedir (OECD, 2013: 47). NTA, mükelleflerin anlayış ve güvenlerini kaybetmemek için mükelleflerin perspektifinden sorunları hızlıca ve içtenlikle cevaplayabilmek için bu birimi kullanmaktadır (NTA, 2017: 51). Mükellef hakları konusunda ise, yayımlanan raporlar ile mükellefler bilgilendirilmeye çalışılmaktadır. Raporda, mükelleflerin bazı özel karşılaşabilecekleri sorunlarda hangi haklarının yer aldığı bulunmaktadır ve tavsiyelerde bulunulmaktadır. Ancak resmi bir mükellef hakları bildirgesi yer almamaktadır.

Japon vergi mevzuatında; mükellef haklarını belirleyen açık hüküm bulunmamakla birlikte, genel mükellef haklarına ilişkin bilgiler yer almaktadır. Ancak günümüzde mükellef haklarının içeriğine yönelik ihtilaf devam etmektedir (Ishimura, 1995: 119). Her ne kadar yayımlanan raporlar aracılığıyla gerekli bilgilendirmeler yapılmaya çalışılsa da kanun içinde mükellef hakları bölümü olması veya mükellef haklarının bildirge haline getirilmesi mükelleflerin lehine olacağı konusu tartışılmaktadır.

Mükelleflerin vergi mahremiyeti konusu, "Ulusal Vergiler Genel Kanunu" (General Law of National Taxes) ve "Ulusal Kamu Hizmeti Kanunu" (National Public Service Act) da dâhil olmak üzere birçok kanunla korunmaktadır. Bu kanunların ihlali durumunda ise idari ve/veya para cezası uygulaması bulunmaktadır. Bir devlet çalışanı bu kanunları ihlal ederse Ulusal Kamu Hizmeti Kanunu ve diğer kanunlarda yer alan disiplin hükümleri uyarınca idari olarak cezalandırılmaktadır. Ancak bazı durumlarda bilgilerin açıklanması talep edilebilir. Mükellefler de ifşa edilen herhangi bir bilgide hataların düzeltilmesini talep etme hakkına sahiptirler (Nakatani ve Ohno, 2015: 467).

İdare mükellef hakları kapsamında, mükelleflerin haklarını ve çıkarlarını korurken kötü niyetli mükelleflere karşı sıkı bir tutum sergilemektedir. Vergilendirmede yapılan hatalar üzerine, mükellefin inceleme aşamasında neleri doğruladığı ve nesnel olarak incelendiğine şüphe olmamalıdır. Mükellef hakları kapsamında bir diğer konu, giderek karmaşıklaşan vergisel işlemlere karşı idarenin sistematik olarak çalışmasıdır. Böylelikle mükelleflerin herhangi bir sorunla karşılaşmamaları için idarenin elinden geleni yaptığı görülmektedir. Ancak bu çerçevede idare uluslararası işlemler için, vergi anlaşmalarına dayalı olarak yabancı vergi otoriteleri ile bilgi değişimi yapmaktadır ve vergi kaçakçılığına karşı sıkı bir tutum sergilemektedir. Aynı zamanda idare, büyük şirketlerin vergisel konularda kurumsal yönetişimin güçlendirilmesi için şirketlerin yöneticileri ile temaslarda bulunarak onların süreçlerini iyileştirme çalışmaları yürütmektedir (NTA, 2017: 8).

Japon hükümeti, yıllık vergi revizyon planı çerçevesinde mükellef haklarının tesis edilmesiyle ilgili açıklamalarda bulunmaktadır. Açıklanan vergi revizyonu kapsamında; idarenin adalet, şeffaflık ve geçerliliğin kendi sloganları olduğunu duyurmuştur. Vergi politikası ve sosyal güvenlik politikası arasında kapsamlı entegrasyon sağlanması, ayrıca vergi sistemleri arasında küreselleşme ve uluslararası iş birliğinin esas olması üzerinde yoğunlaşılmaktadır (Matsubara, 2018: 1). Mükellef hakları kapsamındaki diğer hususlara baktığımızda, mükellefler vergi idaresi tarafından hesaplanan vadesinde ödenmeyen vergiler için gözden geçirme talebinde bulunabilirler. Bu gözden geçirme talebi sistemi, mükelleflerin haklarını ve çıkarlarını basit ve hızlı bir şekilde korumak için geliştirilen bir yöntemdir. Prensip olarak bir amaca hizmet eden bu sistem, mükellefi ilk olarak mahkemeye dava açmadan önce gözden geçirme talebinde bulunmaya yönlendirmektedir (NTA, 2017: 50). Japonya'da mükelleflerin bilgilendirilmesi için de, "beyanname düzenleme kılavuzu" nun yer aldığı görülmektedir. Ayrıca "vergi avantajları rehberi" ve gelir idaresinin internet sitesi aracılığıyla mükelleflerin bilgilendirildiği görülmektedir (Gerçek, 2006: 129). 


\subsection{Anglosakson Hukuk Sistemi}

Geleneksel hukuk sistemi olan Anglosakson hukuk sisteminin halen büyük bir bölümünün kaynağını kanunlar değil, mahkeme kararları oluşturmaktadır. Diğer bir ifadeyle hukuk, büyük ölçüde mahkeme içtihatları tarafından meydana getirilmiştir. Dolayısıyla sistematik bir hukuk düzeninin yokluğu; mahkemenin içtihadı ile olay gruplarına dayalı bir hukuk tekniğini ortaya çıkarmıştır (Güveyi, 2017: 102).

Anglosakson hukuk sistemi sadece içtihatlar ile örf ve adetlere dayanmamaktadır. Bu hukuk sisteminde kanun ve yönetmelik gibi yazılı hukuk kuralları da vardır. Anglosakson hukuk sistemindeki en önemli fark ise, hâkimlere tanınan takdir yetkisi ve kural koyma yetkisinin çok daha geniş, ayrıntılı ve etkili olmasıdır (Kayar ve Üzülmez, 2007: 30). Ayrıca, bu sistemde kamu ve özel hukuk ayrımı görülmemektedir. Hukuk, bütün dallarıyla aynı hukuktur. Özel kişiler arasındaki uyuşmazlıklar hangi hukuka göre çözümleniyorsa, devlet ile özel kişiler arasındaki uyuşmazlıklar da aynı hukuka göre çözümlenir. Yargı birliği ile birlikte yargı kararları temel hukuk kaynağıdır. Yargı birliği sebebiyle, mahkemeler adli mahkemeler ve idari mahkemeler şeklinde ikiye ayrılmamıştır (Gözler, 2009: 134). Ancak bu durum diğer sistemlerde adli ve idari olarak adlandırılan uyuşmazlıkların çözümüne Anglosakson sistemi bakımından engel teşkil etmemekte, söz konusu uyuşmazlıklar nitelikleri bakımından sistem içerisinde çözüme kavuşturulmaktadır. Çalışmada Anglosakson hukuk sistemi, gelişmişlik ölçütü ve mükellef haklarına verilen önem açısından İngiltere, ABD ve Avustralya örnekleri üzerinden incelenmektedir.

\subsubsection{Ingiltere}

Ingiltere'de vergi sisteminin yönetimi ve verginin toplanmasından, 2005 yılında "Comissioners for Revenue and Customs Act" isimli kanun ile İç Gelir İaresi'nin (Inland Revenue and Customs and Excise) yerine kurulan Gelir ve Gümrük İdaresi (HMRC: Her Majesty's Revenue and Customs) sorumludur (HMRC, 2018a). 1986 yılında İngiltere, mükellef hakları bildirgesini (Taxpayer's Charter) ilk kez yayımlamıştır. Daha sonra 1991 yılında, muhafazakâr hükümetin vatandaşlık bildirgesi politikasının bir parçası olarak, mükellef hakları bildirgesi Meclise sunulmuştur. Bildirgeye göre HMRC, mükelleflere yardımcı olmak, etkin bir hizmet sunmak ve ne yapıldığından sorumlu olunabilmesi için adil olmayı taahhüt etmektedir. Ayrıca, mükelleflerin memnun olmadığı ve HMRC tarafından talep edilen standartlara ilişkin nasıl şikâyet edileceği de açıklanmaktadır (James, 2016: 7). Ingiliz gelir idaresi, bildirgelerin gelişimi bakımından öncü konumundadır. Bu sebeple de bildirgelerin çıkarılması konunun sona erdiği anlamına gelmemektedir (James vd., 2005: 5).

2004 yılında İç Gelir Mükellefleri İçin Bildirge (IR167 Charter for Inland Revenue Taxpayers) adı ile bildirge yeniden revize edilmiştir. Belgenin 2004'de yayımlanan versiyonu, idarenin "müşteri hizmetlerine genel yaklaşımı" kapsamınca mükelleflerin kolaylıkla ulaşımının sağlanması için gelir idaresinin web sitesinde yayınlanmıştır (James vd., 2005: 6; Gerçek vd., 2015: 35). Burada HMRC için müşteriden kasıt mükelleflerdir. Mükelleflere, en etkin ve adil hizmetin sunumu ifade edilmektedir. HMRC, 2005 yılındaki değişimle beraber ihtiyaçlarını daha iyi yansıtan bir bildirge için çalışmalar yürütmüştür. Bu doğrultuda da, bölümün sorumluluklarını ve mükelleflerin haklarını ortaya koyabilecek yeni bir bildirge için çalışmalar gerçekleştirmiştir. Ardından HMRC, 2009 Kasım ayında "Sizin Bildirgeniz" (Your Charter) adındaki belgeyi yeniden yayımlamıştır. Bildirgede HMRC; bireylerin, işletmelerin ve diğer organların doğru bilgileri elde etmesine yardımcı olmak ve desteklemek için bir taahhüt vermektedir. Bunun yanı sıra mükelleflerden gelir idaresine karşı dürüst olmalarını, personellerine saygı duyulmasını ve vergisel işlemlerin doğru yapılmasını beklemektedir (Coates \& Co, 2018). Daha sonra birkaç kez daha revize 
geçiren bildirgenin, 2016 Ocak ayında son revizesi yapılmıştır. Bildirgede ${ }^{10}$, idarenin mükelleflerden ne bekleyeceği ve idareden ne beklenmesi gerektiği açıklanmaktadır. İngiltere' de mükellef haklarının gelişim sürecine ilişkin bilgiler Tablo 1'de gösterilmiştir.

Tablo 1: Ingiltere'de Mükellef Haklarının Tarihsel Gelişim Süreci

\begin{tabular}{cc}
\hline Yıllar & Bildirge \\
\hline \hline 1986 & Taxpayer's Charter \\
1991 & Taxpayer's Charter (Revize) \\
2004 & Charter for Inland Revenue Taxpayers \\
2009 & Your Charter \\
2013,2016 & Your Charter (Revize) \\
\hline
\end{tabular}

Kaynak: Tablo tarafımızca oluşturulmuştur.

Mükellef hakları anlamında HMRC'den beklenebilecek olanlar ise, Tablo 2'de yer almaktadır.

Tablo 2: Ingiltere'de Mükellef Hakları

\begin{tabular}{|c|c|}
\hline Mükellef Hakkı & Açıklaması \\
\hline $\begin{array}{c}\text { Mükellefe saygı duyulması ve dürüst } \\
\text { davranılması }\end{array}$ & $\begin{array}{l}\text { Mükelleflere nezaketli ve aynı zamanda eşit davranılacaktır. Endişe- } \\
\text { leri dinlenerek, soruları net bir şekilde cevaplanacaktır. Aksini düşün- } \\
\text { mek için iyi bir neden olmadıkça, idareye doğru söylendiği düşünüle- } \\
\text { cektir. }\end{array}$ \\
\hline $\begin{array}{l}\text { Mükelleflere yararlı, verimli ve etkili bir } \\
\text { hizmet sağlanması }\end{array}$ & $\begin{array}{l}\text { Bu hususta mükelleflere ne yapmaları ve ne zaman yapmaları gerek- } \\
\text { tiğini anlamalarına yardımcı olunacaktır. İdareye verilen bilgiler en } \\
\text { kısa sürede, verimli bir şekilde ele alınacaktır ve herhangi bir masraf } \\
\text { minimumda tutulacaktır. Ayrıca idare elinden geldiğince hataları hızlı } \\
\text { bir şekilde ortaya koyacaktır. }\end{array}$ \\
\hline $\begin{array}{l}\text { Profesyonel olunması ve dürüstlükle ha- } \\
\text { reket edilmesi }\end{array}$ & $\begin{array}{l}\text { Kanun çerçevesinde hareket edilecektir ve konular uzman kişiler tara- } \\
\text { fından ele alınacaktır. Ayrıca, "haklarınızı anlamanıza yardımcı olaca- } \\
\text { ğı ve karşılaşabileceğiniz maddi sıkıntılara karşı duyarlı olacağız" ifa- } \\
\text { desi yer almaktadır. }\end{array}$ \\
\hline $\begin{array}{l}\text { Mükellefin bilgilerinin korunması ve giz- } \\
\text { liliğine saygı gösterilmesi }\end{array}$ & $\begin{array}{l}\text { Mükellefler hakkında elde edilen, alınan veya tutulan bilgiler koruna- } \\
\text { caktır ve sadece kanun izin verdiğinde paylaşılacaktır. Ek bilgi isten- } \\
\text { mesi durumunda da idare neden ek bilgiye ihtiyaç duyduğunu açıkla- } \\
\text { yacaktır. }\end{array}$ \\
\hline $\begin{array}{l}\text { Başka birinin mükellefleri temsil edebile- } \\
\text { ceği kabul edilmektedir. }\end{array}$ & $\begin{array}{l}\text { Muhasebeci ya da ilgili bir başka kişiyle anlaşma yapılması isteğine } \\
\text { saygı gösterilecektir. Mükelleflerin gizliliklerini korumak için temsil } \\
\text { etme yetkisine sahip kişilerle ilgilenilerek, nezih ve profesyonel bir } \\
\text { hizmet verilecektir. }\end{array}$ \\
\hline $\begin{array}{l}\text { Şikâyetler, hızlı ve adil bir şekilde ele alı- } \\
\text { nacaktır. }\end{array}$ & $\begin{array}{l}\text { Mükelleflerin şikâyetleri veya itirazları mümkün olunan en kısa sürede } \\
\text { ele alınacaktır. Ayrıca bir başkasının, mükellefle ilgili konuya ilişkin il- } \\
\text { gilenmesi istenebilmektedir. Eğer aradaki konu yine çözülemezse, an- } \\
\text { laşmazlığa karışmamış başka birisiyle çalışıması talep edilebilir. } \\
\text { Borçlarını ödemeyenler ve geri para talebinde bulunanların talepleri } \\
\text { teşhis edilecektir. Uygun olduğunda ve idarenin gücünü kullanması } \\
\text { gereken mantıklı ve uygun yerlerde faiz ve ceza alınacaktır. }\end{array}$ \\
\hline
\end{tabular}

Kaynak: HMRC (2018b)'den yararlanılarak tarafımızca oluşturulmuştur.

\footnotetext{
${ }^{10}$ Ayrıca mükelleflerin ödevleri de yer almaktadır. Ödevler kapsamında mükelleflerden beklenen, dürüst olunması ve gelir idaresi çalışanlarına saygı duyulması, süreç hakkında bilgilendirilme, muhafaza ve güvenlik, temsil faaliyeti, cevaplandırma ve özen yükümlülüğüdür.
} 
Mükellef hakları konusu kapsamında ele alınabilecek bir diğer husus, İngiltere'de mükellef ile idare arasındaki ilişkilerde ortaya çıkan sorunları değerlendirmek üzere 5 Mayıs 1993 tarihinde kurulan Hakem Ofisi (Adjudicator's Office)'dir. Hakem Ofisi; HMRC ${ }^{11}$, değerleme ofisi kurumu (Valuation Office Agency) ve icra-iflas dairelerine (The Insolvency Service) yönelik şikâyetler için adil ve tarafsız bir hakemlik yapılmasından sorumludur. Hakemlik hizmeti herkes için ücretsiz bir şekilde sunulmaktadır (Aykın, 2015: 148). Hakem Ofisi, alanında uzman ve profesyonel çalışanlarla kendilerine gelen şikâyetleri çözüme ulaştırmaya çalışmaktadır. Ofis, kişilerin ihtiyaçlarını anlayıp onlara makul, verimli, etkili ve esnek hizmet sunarak kaliteli sonuçlar elde etmeyi esas gaye olarak edinmiştir (Özcan, 2016: 121). Birçok ülkede var olan vergi ombudsmanlığı vb. yapıların bir örneği de İngiltere'de görülmektedir. Hakemin bakabileceği şikâyet konuları; hatalı uygulamalar, makul olmayan gecikmeler, yetersiz ya da yanlış yönlendirici nitelikteki bilgilendirmeler, kurum çalışanlarının uygunsuz davranışları, ayrımcılık içeren uygulamalardır.

\subsubsection{ABD}

$A B D$ İç Gelir İdaresi (IRS), köklü bir geçmişe ve gelişmiş bir organizasyon yapısına sahiptir. ABD'de 1990 'lı yıllarda kamusal konuların özellikle vergi toplama işleminden sorumlu IRS personeli tarafından kötüye kullanıldığı konusu sıkça tartışılmaktadır. Mükelleflerin haklarının korunarak IRS'nin işleyişi ile ilgili bir dizi kanun çıkarılmasının planlanması bu tartışmaların bir uzantısı olarak düşünülebilir. ABD'de mükellef hakları konusundaki ilk bildirge, 1988 yılında "Taxpayer Bill of Rights" adıyla ilan edilmiştir. Daha sonra 1996 yılına gelindiğinde ise, "Taxpayer Bill of Rights 2" oluşturulmuştur. Burada ilkine göre, mükelleflerin korunmasına yönelik düzenlemelerin arttırıması amaçlanmıştır. Esas değişim, 1998 yılında "Taxpayer Bill of Rights 3" ile gerçekleşmiştir. Yapılmak istenen düzenlemelerin tamamlanması IRS'de vergisel işlemlerin ve mükellef haklarının korunmasında reform niteliğindeki federal bir kanun olan 1998 Vergi Yeniden Yapılanma ve Reform Kanunu (Tax Restructuring and Reform Act of 1998) ile gerçekleştirilmiştir (Smiley, 2009: 363). Bu kanun ile birlikte mükellef hakları genişleyerek vergi idaresinin içinde bağımsız bir ses olarak mükellefi desteklemek için "mükellefin avukatı idaresi" (Taxpayer Advocate Service) kurulmuştur. Her eyalet, doğrudan ulusal vergi avukatlığına bağlı yerel bir vergi avukatına sahip olup, mükellefin avukatı idaresi normal yollardan çözülemeyen sorunların çözümüne ilişkin yardımcı olmayı hedeflemektedir (Karyağdı, 2006: 35).

Esasen mükellefin avukatı idaresi, vergi idaresi ve mükellefler arasındaki ilişkiyi geliştirmek ve onların ilişkilerinde gerekli güven ortamını sağlamak için kendisini adayarak, mükelleflerin hak ve sorumluluklarının neler olduğu konusunda onlara eğitici-öğretici faaliyetlerde bulunmaktır. Mükellefin avukatı idaresi düzenlediği panellerle mükellefleri dinlemekte, vergi mükelleflerinin problemlerini tespit etmekte ve bunun sonucunda gelir idaresinin sunduğu hizmeti daha iyi hale getirmek ve müşteri (mükellef) memnuniyeti sağlamak için önerilerde bulunmaktadır (TAP, 2018; Gerçek ve Özcan, 2015: 56). Geniş ve karmaşık bir vergi sistemi olan ABD’de, mükellef haklarının önemli bir kısmı hükümet tarafından oluşturulan iç hukuk metinlerinde yer almaktadır. Temel hakların bir listesi, bağlayıcı olmayan mükellef haklarının ihlalini kapsayacak şekilde hazırlanmıştır (Christians, 2016: 1). Bununla birlikte ABD’nin vergi mevzuatındaki değişimler, IRS'nin modernizasyonu kapsamındaki değişiklikler ve güncel gelişmelere paralel olarak değişim göstermiştir. Nitekim mükellef hakları konusunda 2000, 2005 ve 2012 yıllarında sekiz maddelik ilk

\footnotetext{
${ }^{11}$ Hakemlik Ofisi, genellikle HMRC ile ilgili şikâyetlerle ilgilenmektedir.
} 
metinde değişiklikler yapılmış Haziran 2014'te daha kapsamlı bir değişiklik yapılarak bildirge Amerikan Anayasası'nın ilk bölümünde yer alan Haklar Kanunu'na (Bill of Rights) paralel ve benzer şekilde 10 maddelik "Mükellef Hakları Kanunu"na (The Taxpayer Bill of Rights) dönüşmüştür (Abanoz, 2014). Bu konudaki son revize ise, Eylül 2017'de gerçekleştirilmiştir. IRS'nin mükellef hakları konusundaki tarihsel gelişim süreci Tablo 3'te yer almaktadır.

Tablo 3: ABD'de Mükellef Haklarının Tarihsel Gelişimi

\begin{tabular}{cc}
\hline Yıllar & Bildirge/Kanun \\
\hline 1988 & Taxpayer Bill of Rights \\
1996 & Taxpayer Bill of Rights 2 \\
1998 & Taxpayer Bill of Rights 3 \\
2005,2012 & Your Rights as a Taxpayer (Revize) \\
2014 & The Taxpayer Bill of Rights (Kanun haline dönüşmüştür) \\
2017 & The Taxpayer Bill of Rights (Revize) \\
\hline
\end{tabular}

Kaynak: Tablo tarafımızca oluşturulmuştur.

Her vergi mükellefi IRS ile iş ve işlemlerinde farkında olması gereken bir dizi temel haklara sahiptir. Mükelleflerin hakları ve IRS'nin onları koruma konusundaki yükümlülükleri Tablo 4'te yer almaktadır.

Tablo 4: ABD’de Mükellef Hakları

\begin{tabular}{|c|c|}
\hline Mükellef Hakkı & Açıklaması \\
\hline $\begin{array}{l}\text { Bilgilendirilme Hakkı (The Right to Be In- } \\
\text { formed) }\end{array}$ & $\begin{array}{l}\text { Mükellefler vergi kanunlarına uyum sağlamak için ne yapmaları ge- } \\
\text { rektiğini bilme hakkına sahiptir. Mükellefler vergi kanunları ile IRS'nin } \\
\text { vergi beyanname ve formları, açıklamaları, yayınları, ihbarnameleri ve } \\
\text { yazışmaları hakkında net açıklamayı hak etmektedirler. Mükellefler } \\
\text { vergi hesaplarıyla ilgili, IRS kararlarından haberdar olma ve sonuçla- } \\
\text { rıyla ilgili net açıklama alma hakkına sahiptir. }\end{array}$ \\
\hline $\begin{array}{c}\text { Kaliteli Hizmet Alma Hakkı (The Right to } \\
\text { Quality Service) }\end{array}$ & $\begin{array}{l}\text { Mükellefler; IRS ile ilişkilerinde hızlı, saygılı ve profesyonel hizmet } \\
\text { alma, kolayca anlayabilecekleri şekilde konuşma, kendileri ile net ve } \\
\text { anlaşılır biçimde iletişim kurulma ve yetersiz bir hizmet durumunda } \\
\text { yetkili biri ile görüşebilme hakkına sahiptir. }\end{array}$ \\
\hline $\begin{array}{l}\text { Gerçek Miktarın Üzerinde Vergi Öde- } \\
\text { meme Hakkı (The Right to Pay No More } \\
\text { Than the Correct Amount of Tax) }\end{array}$ & $\begin{array}{l}\text { Mükellefler sadece kanun gereği tahakkuk etmiş vergi ile faiz, cezaları } \\
\text { ödeme ve IRS'nin tüm vergi ödemelerini düzgün bir şekilde uygulama- } \\
\text { sına izin verme hakkına sahiptir. }\end{array}$ \\
\hline $\begin{array}{l}\text { IRS'nin Kararları ile Mücadele Etme ve } \\
\text { Karşılık Hakkı (The Right to Challenge the } \\
\text { IRS's Position and Be Heard) }\end{array}$ & $\begin{array}{l}\text { Mükellefler IRS'nin kendileri ile ilgili mevcut ya da önerilmiş işlemle- } \\
\text { rine karşı itiraz etme ve ek doküman sunma hakkına sahiptir. Ayrıca, } \\
\text { mükelleflerin süresinde yapılmış itirazlar ile sunulan belgelerin derhal } \\
\text { ve adil şekilde dikkate alınıp değerlendirilmesi ve bu itirazların kabul } \\
\text { görmemesi durumunda kendilerine cevap verilmesi hakları bulun- } \\
\text { maktadır. }\end{array}$ \\
\hline $\begin{array}{l}\text { IRS Kararlarına Karşı Bağımsız Bir Birime } \\
\text { Başvuru Hakkı (The Right to Appeal an } \\
\text { IRS Decision in an Independent Forum) }\end{array}$ & $\begin{array}{l}\text { Mükellefler, IRS'nin çoğu kararları ile uyguladı̆̆ı birçok cezalara karşı } \\
\text { adil ve tarafsız idari itiraz yoluna gitme ve itiraz kurulu kararlarını yazılı } \\
\text { olarak alma hakkına sahiptirler. Mükellefler, durumlarını mahkemeye } \\
\text { taşıma hakkına da sahiptir. }\end{array}$ \\
\hline Kesinlik Hakkı (The Right to Finality) & $\begin{array}{l}\text { Mükellefler IRS'nin iş ve işlemlerine karşı ne zamana kadar mücadele } \\
\text { edeceklerini, IRS'nin belirli bir vergilendirme dönemini ne zamana ka- } \\
\text { dar inceleyebileceğini ve vergi borcunu ne zamana kadar tahsil edebi- } \\
\text { leceğini bilme hakkına sahiptirler. Ayrıca mükellefler, IRS'nin incele- } \\
\text { meyi ne zaman sonuçlandıracağını bilebilmelidir. }\end{array}$ \\
\hline
\end{tabular}




\begin{tabular}{|c|c|}
\hline Gizlilik Hakkı (The Right to Privacy) & $\begin{array}{l}\text { Mükellefler IRS'nin araştırma, inceleme ve kanun uygulama faaliyet- } \\
\text { lerinin kanuna uygun olacağını ve gerekenden daha fazla müdahalede } \\
\text { bulunulmamasını bekleme hakkına sahiptir. Ayrıca mükellefler, takip } \\
\text { ve tahsilat süreçlerinin adil ve yerinde olacağını bekleme hakkına sa- } \\
\text { hiptirler. }\end{array}$ \\
\hline $\begin{array}{c}\text { Sırların Korunması Hakkı (The Right to } \\
\text { Confidentiality) }\end{array}$ & $\begin{array}{l}\text { Mükellefler IRS'ye verdikleri bilgilerin kendileri veya kanun hükümle- } \\
\text { rince uygun görülmedikçe açıklanmayacağını bekleme hakkına sahip- } \\
\text { tir. Mükellefler beyannamelerinde yer alan bilgilerin IRS çalışanları, } \\
\text { beyannameyi hazırlayanlar ya da diğer kişiler tarafından açılanması } \\
\text { veya kötü amaçla kullanımı halinde önlemlerin alınmasını bekleme } \\
\text { hakkına sahiptir. }\end{array}$ \\
\hline $\begin{array}{c}\text { Temsil Hakkı (The Right to Retain Repre- } \\
\text { sentation) }\end{array}$ & $\begin{array}{l}\text { Mükellefler, IRS ile ilişkilerinde istedikleri yetkili temsilciyi seçme hak- } \\
\text { kına sahiptirler. Mükelleflerin, kendilerini temsil edecek kişinin mali- } \\
\text { yetlerini karşılayamadıkları taktirde düşük gelirli mükellefler kliniğin- } \\
\text { den (Low Income Taxpayer Clinic) yardım isteme hakkı bulunmakta- } \\
\text { dır. }\end{array}$ \\
\hline $\begin{array}{l}\text { Eşit ve Adil Vergi Sistemi Hakkı (The } \\
\text { Right to a Fair and Just Tax System) }\end{array}$ & $\begin{array}{l}\text { Mükellefler, vergi sisteminin temel yükümlülüklerini, ödeme kabili- } \\
\text { yetlerini veya zamanında bilgileri sağlama kabiliyetlerini etkileyebile- } \\
\text { cek özel durum ve koşulları dikkate almalarını bekleme hakkına sahip- } \\
\text { tirler. Mükelleflerin, mali zorluk yaşaması veya vergisel problemleri } \\
\text { IRS tarafından kendi iç mekanizmalarıyla zamanında ve gerektiği gibi } \\
\text { çözümlenemediği durumda mükellefin avukatı idaresinden yardım } \\
\text { alma hakkı mevcuttur. }\end{array}$ \\
\hline
\end{tabular}

Kaynak: IRS (2018)'den yararlanılarak tarafımızca oluşturulmuştur.

\subsubsection{Avustralya}

Avustralya Vergi Idaresi (Australian Taxation Office, ATO), Avustralya hükümetinin temel gelir toplama kuruşudur. ATO, 1 Temmuz 1997 tarihinde yayımladığı mükellef hakları bildirgesini dünyadaki çeşitli bildirgeleri inceleyerek ve katılımcı bir süreç içerisinde paydaşların görüşlerini alarak hazırlamıştır. Bu süreçte ATO çalışanları, halk, iş dünyası ve halktan çeşitli topluluklar, vergi temsilcileri ve diğer devlet kurumlarıyla ortak çalışmalar yürütmüştür. Mükellef hakları bildirgesi, mükellefler için kanuni yetki ve mevcut sistemde var olmayan yeni bir hukuki hak yaratmamıştır. Tersine ATO'nun hizmet standartlarını vurgulamış, mükelleflerin ATO'dan bekleyeceği "halkla ilişkileri geliştirmeyi" amaçlamıştır. Bildirgeyle beraber, mükelleflerin mevcut hukuki haklarının ve ödevlerinin basit bir dille açıklanması gerçekleşmiştir (Gerçek vd., 2015: 41-42). Mükellef hakları bildirgesiyle amaçlanan, mükelleflerin vergi hukuku kapsamındaki ödevlere uymaya çalıştıklarında, mükellefleri koruyan bir mekanizmanın sağlanmasıdır. Aynı zamanda, mükelleflerin temel yasal haklarını etkili bir uyum çerçevesi bağlamında korumak ve böylece mükellef ile idare arasındaki ilişkinin karşılıklı olarak güçlendirilmesini sağlamaktır (Bentley, 2016: 294).

Mükellef hakları kapsamında değerlendirilebilecek olan "vergilendirme ombudsmanı" (Taxation Ombudsman) gelir idaresinden bağımsız bir şekilde, sorunlara ilişkin sistematik raporlama yaparak mükelleflere yardımcı olan bir kurum olarak düşünülebilir. Vergi sorunları ile ilgili görüş bildiren ve vergi sistemini geliştiren fonksiyonları bulunan ombudsman, yıllık raporlar aracılığıyla bu fonksiyonlarını dolaylı olarak yerine getirme gücüne sahiptir. Bu yüzden mükelleflere ciddi bir danışmanlık hizmeti sunmaktadır (Gerçek ve Özcan, 2015: 58). Aynı zamanda vergi uyuşmazlıklarını da çözen ombudsman oldukça fonksiyonel bir yapıya sahiptir.

Avustralya'da her şeye rağmen vergisel anlamda beklentilerin karşılanamamasıyla beraber bir reforma ihtiyaç duyulmuştur ve bu reform 1 Temmuz 2000 tarihinde gelir vergisi, kurumlar vergisi ile mal ve hizmetler vergilerinde yapılmıştır. Bu sebeple de mükellef hakları bildirgesinin 
revizesi gecikmiştir. Bu süreçte mükelleflerin ATO ile ilgili görüşleri de alınarak Kasım 2003'te bildirge yayımlanmıştır (Bevacqua, 2012: 236). Bildirge, önceki bildirgenin uzun olduğu gerekçesiyle "Bilmeniz Gerekenler" (Taxpayer Charter-What You Need to Know) adında özet niteliktedir. Fakat bu bildirgenin de yetersiz gelmesi hasebiyle "detaylı olarak" (Taxpayer Charter-In Detail) adında bir kitapçık oluşturulmuştur. Burada amaç mükellef haklarının ayrıntılı bir şekilde anlaşılmasıdır. Daha sonra ise, Temmuz 2010 'da yeni bir mükellef hakları bildirgesi ${ }^{12}$ yayımlanmıştır. Bu bildirgede de, eski bildirgeye bağlı kalınmış ancak daha net ifadelere yer verilmeye çalışılmıştır (ATO, 2018a; Gerçek vd., 2015: 42). Avustralya'da 2010 yılında yayımlanan son bildirge, 15 Şubat 2017 tarihinde revize edilmiştir. Buna göre (ATO, 2018b; Aydın, 2006) ${ }^{13}$ :

> Mükelleflere Adil, Eşit ve Makul Ölçülerde Davranılması Hakkı: Vergi idaresi; mükelleflere nazik, düşünceli ve saygılı davranacaktır. Bunları yaparken aynı zamanda tarafsız hareket ederek adil ve eşitlikçi kararlar verecektir.

$>$ Aksi İspatlanmadığı Sürece Mükellefin Dürüst Olduğu ve Kendisine Bu Şekilde Davranılmasını Bekleme Hakkı: Mükellef, aksi ispatlanmadığı sürece dürüst ve iyi niyetli bir birey olarak kabul edilmektedir. Ancak yanlışlıkla ve bilerek yapılan hareketlerin ayrımı yapılmaktadır. Mükellefler yanlışlık yaparlar ise, bunu açıklamak için fırsat tanınmaktadır.

$>$ Mükellefin Vergisel Yükümlülüklerini Anlaması ve Yerine Getirebilmesi ile ilgili Her Türlü Yardımı Alma Hakkı: Mükelleflere, ihtiyacı olduğunda daha fazla bilgi alabilmeleri için iletişim bilgilerinin ayrıntıları verilir. Ancak mükellefin daha karmaşık bir sorunu olursa, kendisine yardım edecek biriyle iletişime geçme hakkı vardır.

> Mükellefin Temsilci Seçebilme ve Vergi İşlerinde Danışmanlık Hizmetinden Yararlanabilme Hakkı: Mükellefler, vergisel ödevlerini bizzat kendileri yapabilecekleri gibi kendilerinin belirleyeceği bir temsilci aracılığıyla da yürütebilirler. Bu durumda mükellefler idareyle olan işlerini gerçekleştirmeleri için farklı kişileri temsilci seçebilir veya yetkilendirebilir. Ancak, bir kişinin mükellefin adına hareket etmesi veya işlerini yapması durumunda idareye bilgi verilmelidir.

> Mükellefin Gizlilik Hakkı: Kanunlar uygulanırken, mükellefler hakkında bilgi toplanmaktadır. Bu bilgiler mükelleften veya başkalarından alınabilmektedir. Ancak mükelleflerin gizliliğine saygı gösterilmesi ve bilgilerin gizli tutulması gerekmektedir. Kimi durumlarda kanun, idareye mükelleflere ait bilgileri belirli amaçlar için başkalarına açıklaması için izin vermektedir.

$>$ Mükellefe Ait Sırların Saklı Tutulması Hakkı: Vergi kanunlarında, mükelleflere ait bilgilerin kullanılması ve açıklanmasına ilişkin gizlilik hükümleri vardır. Mükelleflere ait bilgiler idarenin işinin gerekli bir parçası ise veya kanunun idareye bunu yapabileceğini belirttiği yerlerde kaydedebilir, üzerinde konuşabilir veya açıklayabilir.

$>$ Mükellefin Bilgilendirilme Hakkı: Avustralya'da 1982 yılında çıkarılan Bilgiye Erişim Özgürlüğü Kanunu (The Freedom of Information Act) gereğince mükelleflere, idarede bulunan belgelere erişim hakkı tanınmaktadır. Ayrıca, idarenin karar vermesine yardımcı olan kanun

\footnotetext{
12 Bildirge aralarında Türkçe'nin de olduğu 20 farklı dilde yazılarak değişik kültürdeki mükelleflerin anlamasını sağlayacak şekilde hazırlanmıştır.

${ }^{13}$ Aynı zamanda bildirgede çok sayıda ödev sayılmaktadır. Dürüst olmak, gerekli kayıtları saklamak, makul özenin gösterilmesi, vergilerin zamanında ödenmesi, vergi ile ilgili beyanname ve bildirimlerin vergi dairesine süresinde verilmesi, vergi idaresi ile iş birliği içinde olması mükelleflerin ödevleri arasında yer almaktadır.
} 
hükümleri, ATO işlemleri ve kuralları gibi belgelere de mükelleflerin erişimi mümkün olmaktadır.

> Mükellefin Doğru Bilgi ve Tavsiyeleri Alma Hakkı: Vergi idaresi mükellefe eksiksiz, doğru, tutarlı bilgi ve önerileri vermeyi hedeflemektedir. Bunu, mükelleflerin vergisel ödevlerini anlamalarına yardımcı olmak, bu ödevleri yerine getirmelerini ve mükellefin sahip olduğu hakların ve kazanımların farkında olmasını sağlamak amacıyla yapmaktadır.

> Vergi ile illgili İşlemler Hakkında Açıklama İsteme Hakkı: Genellikle idare, kararlarını yazılı olarak vermektedir ve ilgili konuda açıklama yapmaktadır. İdare kararını mükellefe sözlü olarak bildirirse, açıklamayı da aynı zamanda yapması gerekmektedir.

$>$ Gözden Geçirme Hakkı: İdare, mükellefin işlemleri hakkında kendilerine bir karar bildirirse, onlara kararın yeniden gözden geçirilmesini nasıl sağlayabileceğini de açıklar ve zaman sınırları olup olmadığını söylemektedir. Birkaç gözden geçirme seçeneği varsa, bunların farkını da anlatmaktadır.

$>$ Şikâyette Bulunma Hakkı: Mükellef; idarenin kararlarından, hizmetinden veya icraatından memnun kalmamışsa, şikâyette bulunma hakkı vardır. Ancak vergi idaresi, mükellef hakları bildirgesi ile açıklamış olduğu tüm hizmetleri yerine getirmekle ve ifade edilen tüm standartları sağlamakla yükümlüdür. Mükellef sorun yaşadığında, sorununu önce sorun yaşadığı vergi memuru ile çözmeye çalışmalıdır. Tatmin olmazsa, vergi memurunun müdürü ile görüşmelidir. Eğer yine memnun kalmaz ise, ilgili iletişim bilgilerinden ${ }^{14}$ şikâyetini iletebilir.

$>$ Mükelleflerin Kanunlara Uyumunu Kolaylaştırma Hakkı: Mükellefin idareyle olan işlerini, idare mümkün olduğunca açık ve elverişli bir şekilde yapmaya çalışır. Bu anlamda mükellefin; yükümlülüklerini ve onları nasıl yerine getirebileceğini anlamasını kolaylaştırarak, kanunlara uymalarını, gereken iş yükü, zaman ve çabayı azaltıp daha ucuz hale getirerek yapmaya çalışmaktadır. Bunların hepsini verimli yapabilmek adına, düzenli olarak topluma danışır, toplumu ürün ve hizmetlerinin tasarımına katar, model ürün ve hizmetlerini, onları kullanacak kişilerle deneyerek rasyonelliği sağlar.

> Vergi İdaresinin Yaptığı İşlemlerden Sorumlu Olması: Vergi idaresi mükellef hakları bildirgesinde yer alan ödevlerin tam olarak yerine getirilmesi konusunda kamuoyuna ve Parlamento'ya karşı sorumludur. Bunun gerçekleşmesi için yapılan çalışmaların sonuçları hakkında raporlar hazırlamakta ve bu raporları kamuoyu ile paylaşmaktadır.

Mükellef hakları, ATO'nun da destekleriyle mükelleflerle birlikte istikrarlı ve uyumlu yönetimi amaçlamaktadır. Esas olarak uluslararası eğilimler ve potansiyel zorluklar iki temel kaygıya dikkat çekmektedir. Biri temel yasal hakların zayıflamasıyla ilgilidir. Diğeri ise, idarenin gelir tabanına yönelik tehditlere karşı tepkileridir. Bu anlamda geleneksel vergilendirme yöntemlerinin etkinliğini sağlayabilmek adına mükellef haklarına büyük rol düşmektedir (Bentley, 2016: 317318).

${ }^{14}$ Mükellefler, www.ato.gov.au aracılı̆̆ıla şikâyetini iletebilir. 


\section{Sonuç}

1215 Magna Carta'dan bu yana mükellef hakları tarihsel olarak gelişim göstermektedir. Bu süreç, her ülke açısından farklı olmakla birlikte mükellef hakları konusunda ön plana çıkan bazı ülkeler bu konuda örnek alınmaktadır. Özellikle, mükellefi odak noktasına almayan bir gelir idaresinin gerekli modernizasyonu sağladığını söyleyebilmek mümkün değildir.

Çalışma kapsamında seçilen ülkelerden biri olan Fransa, mükellef hakları konusundaki revizeleri doğrultusunda yayımladığı bildirgeyi, hem idarenin hem de mükelleflerin hak ve sorumluluklarını içeren bir bildirge kapsamına dönüştürmüştür. Fransız mükellef hakları bildirgesinin kapsamlı ve detaylı bir şekilde hazırlandığı göze çarpmaktadır. Almanya'nın ise, mükellef hakları konusunu bildirge yerine Alman Vergi Usul Kanunu'nda düzenlediği görülmektedir. Birçok ülkede yer alan klasik haklar olan dilekçe hakkı, vergi mahremiyeti hakkı gibi haklara Almanya'da da rastlanılmaktadır. Japonya da mükellef hakları konusunda çeşitli çalışmalar yürüten gelişmiş ülkelerden biridir ancak Japon mevzuatında mükellef haklarını belirten açık hüküm olmamasından dolayı, mükellef haklarını toplu bir şekilde görememekteyiz. Japon vergi idaresi, mükellef hakları konusunda bir bildirge de düzenlememiştir. Ancak, NTA'nın yayımladığı raporlar aracılığıyla mükellefler bilgilendirilmektedir.

Ingiltere zamanın koşullarına uygun hale getirdiği mükellef hakları bildirgesiyle, mükelleflerin haklarını korumaktadır. Aynı zamanda hakem ofisi uygulamasıyla alanında uzman ve profesyonel çalışanlar, mükellefler tarafından gelen şikâyetleri çözüme kavuşturmaya çalışmaktadırlar. ABD ise, mükellef hakları konusunda kanun ile düzenleme yapan ülkelerdendir. IRS, geçmişten bu yana gerek bildirge ile gerekse kanun ile düzenleme yapmıştır. Mevcut on maddelik kanuna göre; bilgilendirilme hakkı, kaliteli hizmet alma hakkı, gizlilik hakkı, temsil hakkı, eşit ve adil vergi sistemi hakkı gibi haklar görülmektedir. IRS'nin mükelleflerin ödevlerini anlama ve yerine getirme konusunda yardım etmeyi misyon olarak edinmesini yaptığı birçok çalışmadan görebilmekteyiz. Ayrıca mükellefin avukatı idaresi ile, mükellefin sorunlarına hızlı bir şekilde çözüm bulmak hedeflenmiştir. Avustralya gelir idaresi her ne kadar mükellef hakları konusunda geç çalışmaya başlamış olsa da şu an oldukça ileri bir durumdadır. Düzenlediği mükellef hakları bildirgesiyle mevcut sorunlara yeterli gelen bir konumdadır. Ayrıca, vergi ombudsmanlığı ile de mükellef hakları konusuna verdiği önemi göstermektedir.

Seçilen gelişmiş ülkeler kapsamında konuya baktığımızda olması gereken bakımından ülkelerin geçirdiği süreçler konusunda normatif yaklaşım, mevcut hukuki durumda gelinen noktalar bakımından pozitif yaklaşım ele alınmaya çalışılmıştır. Bildirge örneklerine baktığımızda, İngiltere'nin bildirgesinde mükelleflerin hak ve ödevleri sayılırken, ABD sadece haklara yer vermiştir; Avustralya hak ve ödevleri ayrıntılı açıklarken, Japonya bu tip bir düzenlemeye gitmemiştir. Ayrıca başka bir farklılık, ABD ve Almanya mükellef hakları konusunda kanunla düzenleme yaparken İngiltere, Avustralya, Fransa bildirge ile düzenleme yoluna gitmiştir. Ülkeler incelendiğinde her ülkede uygulanma imkânı olan standart bir bildirgenin olmadığı göze çarpmaktadır. Bazı ülkeler, vergilendirme süreci aşamasındaki hakları daha detaylandırırken, diğerleri daha genel olarak haklardan bahsetmiştir. Tüm bu hususlar birlikte değerlendirildiğinde, mükellef haklarının kanun ile düzenlenmesinin mükelleflerin lehine olacağı kanaatindeyiz. Bir bildirge ile kanunun yaptırım gücü dikkate alındığında, kanuna dayalı ve somut olarak ortaya konulan mükellef haklarının mükelleflerin ödevleri karşısında daha önemli bir konum alacağı söylenebilir. Çalışmada mükellef hakları konusunda seçilmiş ülke uygulamaları ele alındığından Türkiye' deki mevcut durum değerlendirilmemekle beraber, kuşkusuz söz konusu örnek uygulamalardan yola çıkılarak Türkiye açısından başka çalışmalara konu olabilecek çeşitli öneriler geliştirilebilir. 


\section{Eskişehir Osmangazi Üniversitesi IïB Dergisi}

\section{Kaynaklar}

Abanoz, Mehmet (2014), “Gönüllü Uyum İçin Bir Öneri: “Mükellef Hakları Bildirgesi” Revize Edilmeli Midir?”, Yaklaşım Dergisi, S. 261, (Eylül), http://uye.yaklasim.com/MagazineContent.aspx?ID=26277, (Erişim: 05.01.2018).

Anayurt, Ömer (2018), Hukuka Giriş ve Hukukun Temel Kavramları, Güncellenmiş 18. Baskı, Ankara: Seçkin Yayıncılık.

ATO (2018a), "Taxpayer's Charter", https://www.ato.gov.au/About-ATO/About-us/In-detail/Taxpayers-charter/Yourrights-and obligations/, (Erişim: 02.08.2018).

ATO (2018b), https://www.ato.gov.au/About-ATO/About-us/In-detail/Taxpayers-charter/Taxpayers--charter---whatyou-need-to-know/?page=3\#Your_rights, (Erişim: 02.08.2018).

Aydın, Selda (2006), "Mükellef Hakları Bildirgesi: Avustralya Örneği”, Vergi Sorunları Dergisi, S. 214, (Temmuz), http://www.vergisorunlari.com.tr/makale/mukellef-haklari-bildirgesi-avustralya-ornegi/1916, 02.08.2018).

Aykın, Hasan (2015), "Mükellef Haklarında Yeni ve Illeri Bir Aşama: Vergi Mükellefi Ombudsmanlı̆ı", Vergi Sorunları Dergisi, S. 316, (Ocak): 146-151.

Bentley, Duncan (2002), "The Signifance of Declarations of Taxpayers' Rights and Global Standards for the Delivery of Tax Services by Revenue Authorities", Law papers, Bond University Law Faculty Publications, http://epublications.bond.edu.au/cgi/viewcontent.cgi?article=1034\&context=law_pubs, (Erişim: 17.01.2018).

Bentley, Duncan (2007), Taxpayers' Rights: Theory, Origin and Implementation, Series on International Taxation, Kluwer Law International, The Netherlands.

Bentley, Duncan (2016), "Taxpayer Rights in Australia Twenty Years After the Introduction of the Taxpayers' Charter", EJournal of Tax Research, Vol. 14, No. 2, (November): 291-318.

Bevacqua, John (2012), "Australian Business Taxpayer Rights to Compensation for Loss Caused by Tax Official Wrongs - a Call for Legislative Clarification", EJournal of Tax Research, Vol. 10, No. 2, (October): 227-249.

Brzezinski, Bogumil (2009), "Taxpayers' Rights: Some Theoretical Issues”, (Ed. Wlodzimierz Nykiel, Malgorzata Sek), Protection of Taxpayer's Rights European, International and Domestic Tax Law Perspective, Warszawa: Oficyna a Wolters Kluwer Business: 17-32.

Christians, Allison (2016), "Taxpayer Rights in the United States”, (Ed. Cesar Alejandro Ruiz Jimenez), Tax Law and Human Rights: 1-18.

Coates \& Co (2018), https://www.coatesca.co.uk/data/enews_article.asp?ID=1682\&AID=1782\&CID=4, (Erişim: 05.04.2018).

Çetin, Güneş; Gökbunar, Ramazan (2010), “Mükellef Haklarına Vergi İdaresi Çalışanlarının Bakışı”, Yönetim ve Ekonomi: Celal Bayar Üniversitesi Iktisadi ve Idari Bilimler Fakültesi Dergisi, C. 17, S. 1: 23-46.

Direction Générale des Finances Publiques (2018), "La Charte des Droits et Obligations du Contribuable Vérifié", Le Contrôle Fiscal et La Lutte Contre La Fraude https://www.economie.gouv.fr/files/files/directions_services/dgfip/controle_fiscal/organisation_fonctionnement/charte_aout_2018.pdf, (Erişim: 10.10.2019).

Federal Almanya Cumhuriyeti Anayasası, http://www.adalet.gov.tr/duyurular/2011/eylul/anayasalar/ulkeana/pdf/08ALMANYA\%20209-276.pdf, (Erişim: 21.07.2018).

Gerçek, Adnan (2006), "Vergilemede Mükellef Hakları ve Türkiye'deki Durumun İncelenmesi”, Vergi Sorunları Dergisi, S. 209, (Şubat): 121-149.

Gerçek, Adnan; Özcan, Onur (2015), “Vergi Ombudsmanı: Fonksiyonları, Değişik Ülke Uygulamaları ve Türkiye için Çıkarımlar", Vergi Sorunları Dergisi, S. 324, (Eylül): 49-64.

Gerçek, Adnan; Çetin Gerger, Güneş; Taşkın, Çağatan; Bakar, Feride; Güzel, Simla (2015), Mükellef Hakları Türkiye Perspektifi ve Geliştirilmesi, Ankara: Seçkin Yayıncılık.

Gökbel, Doğan (2000), Mükellef Hakları, Doktora Tezi, Eskişehir: Anadolu Üniversitesi Sosyal Bilimler Enstitüsü.

Gözler, Kemal (2009), Hukuka Giriş, Güncelleştirilmiş ve Düzeltilmiş 6. Baskı, Bursa: Ekin Basım Yayın Dağıtım.

Güveyi, Nazmiye (2017), “Anglo-Sakson Hukuk Sistemi ve Kara Avrupası Hukuk Sitemi Boyutuyla Ekonomik İdare Hukuku Üzerine Bazı Düşünceler”, Gazi Üniversitesi Hukuk Fakültesi Dergisi, C. XXI, S. 1: 83-122.

HMRC (2018a), "About Us", https://www.gov.uk/government/organisations/hm-revenue-customs/about, (Erişim: 30.03.2018).

HMRC (2018b), "Your Charter", https://www.gov.uk/government/publications/your-charter/your-charter, (Erişim: 05.04.2018). 
IRS (2018), "Your Rights as a Taxpayer", Department of the Treasury, Publication 1, https://www.irs.gov/taxpayer-billof-rights, (Erişim: 20.05.2018).

Ishimura, Koji (1995), The State of Taxpayers' Rights in Japan a Survey of the Legal Situation, Japan: Asahi University, Institute for International Trade Law, Gifu.

James, Malcolm (2016), The UK Tax System: An Introduction, 3. Edition, Spiramus Press.

James, Simon; Murphy, Kristina; Reinhart, Monika (2005), The Taxpayers' Charter: A Case Study in Tax Administration, The Australian National University Centre for Tax System Integrity, Working Paper No. 62.

Karataş Durmuş, Neslihan (2015), “Türk ve Fransız Vergi Hukuku Kapsamında Mükelleflerin Korunması”, 30. Türkiye Maliye Sempozyumu Bildiri Kitabı, Adnan Menderes Üniversitesi Nazilli iiBF Maliye Bölümü: 109-136.

Karataş Durmuş, Neslihan (2016), "Türk ve Fransız Vergi Hukuku Kapsamında Mükelleflerin Korunması”, Erciyes Üniversitesi Iktisadi ve Idari Bilimler Fakültesi Dergisi, S. 48, (Temmuz-Aralık): 99-122.

Karyağdı, Nazmi (2006), Amerika Birleşik Devletleri Gelir Idaresi'nde Vergi Incelemesi, Ankara: Maliye Bakanlığı Strateji Geliştirme Başkanlığı, Yayın No. 2006/371.

Kaya, Mustafa Göktuğ; ilik, Hüseyin Kamil; Türkmen, Hakan (2017), Uluslararası Vergi Sistemi ve Denetim: Türkiye, ABD, Ingiltere ve Diğer Ülkeler, 2. Basım, Ankara: Nobel Bilimsel Eserler.

Kayar, İsmail; Üzülmez, İlhan (2007), Hukukun Temel Kavramları, Güncelleştirilmiş 4. Baskı, Ankara: Detay Yayıncılık.

Matsubara, Yuri (2018), "Tax Transparency", National Report in Japan.

Nakatani, Eiichiro; Ohno, Masato (2015), "General Report”, The Practical Protection of Taxpayers Fundamental Rights, International Fiscal Association 2015 Basel Congress Cahiers, Vol. 100, No. 2: 461-480.

NTA Japan Report (2017), https://www.nta.go.jp/english/Report_pdf/2017e.pdf, (Erişim: 14.08.2018).

OECD (2003), OECD Committee of Fiscal Affairs Forum on Tax Administration, Taxpayer' Rights and Obligations Practice Note.

OECD (2013), Tax Administration 2013, Comparative Information on OECD and Other Advanced and Emerging Economies, OECD Publishing.

Organ, İbrahim (2008), Vergi Denetimi ve Türkiye Uygulaması, Ankara: Gazi Kitabevi.

Özcan, Onur (2016), “Ombudsman Kurumunun Vergi Ombudsmanı Özelinde İncelenmesi: İngiltere Hakem Ofisi Örneği”, Vergi Dünyası Dergisi, S. 413, (Ocak): 117-126.

Reimer, Ekkehart (2009), "National Report on Taxpayer Protection in Germany", (Ed. Wlodzimierz Nykiel, Malgorzata Sek), Protection of Taxpayer's Rights European, International and Domestic Tax Law Perspective, Warszawa: Oficyna a Wolters Kluwer Business: 200-231.

Smiley, Stafford (2009), "National Report on Taxpayer Protection in the United States of America", (Ed. Wlodzimierz Nykiel, Malgorzata Sek), Protection of Taxpayer's Rights European, International and Domestic Tax Law Perspective, Warszawa: Oficyna a Wolters Kluwer Business: 349-364.

Taxpayer Advocate Service, Taxpayer Advocacy Panel (TAP 2018), https://www.irs.gov/advocate/taxpayer-advocacypanel, (Erişim: 17.11.2018).

Tieghi, Giovanna (2015), "Taxpayer Rights: A Constitutional Perspective the Italian Taxpayer Bill of Rights 15 Years on 'at the Top of the World'. But What About Effectiveness?", Washington: 1. International Conference on Taxpayer Rights: 1-29.

Vanistendael, Frans (1996), "Legal Framework for Taxation", (Ed. Victor Thuronyi), Tax Law Design and Drafting, International Monetary Fund, Vol. 1: 15-70.

Yurtsever, Hatice (2010), “Anatomy of Taxpayers' Rights: Case Study of Turkey”, Pakistan Journal of Social Sciences, Vol. 7, No. 5: 334-346. 


\section{Extended Summary}

\section{Evaluations about the Taxpayer Rights in the context of the Selected Countries}

Significant changes and developments have been experienced on the subject of taxpayer rights from the past to the present. It can be said that the taxpayer rights have emerged as a result of the fundamental human rights in the general legal order reflect in the tax law. Nowadays the definition of the taxpayer rights has become increasingly important for countries. Therefore, the relationships between taxpayers and revenue administration have developed and became transparent more and more. If the acquiring of the taxpayer rights has been considered as a process that starts with the restructuring of the revenue administrations, in this area the developed countries belonging to the different legal systems come to the fore. These countries engage in various research, coordinate their activities at various working levels and engage in close dialogue with each other to provide better service to taxpayers and to protect their rights.

The aim of this study is to address the issue of taxpayer rights in some selected developed countries from the perspective of the understanding of law order belonging to Continental European or Anglo-Saxon systems. In this context, the subject of taxpayer rights in France and Germany were evaluated as the countries that adopted the Continental European legal system. On the other hand, although it has been shaped partly by the Anglo-Saxon law system, Japan which mainly adopts the Continental European legal system, has been evaluated as a separate example. The countries England, USA and Australia have also been examined as the most important examples from the Anglo-Saxon legal system. It is important that such examples of countries can give ideas in terms of comparative studies to be carried out in the future.

Although there are similar developments in country practices, it attracts attention that different understandings can emerge about the position of taxpayer rights. In terms of country practices, taxpayer rights can establish itself in laws, declarations or reports. Taxpayer rights declarations aim to the rights of taxpayers summarize clearly in terms of taxation process and to make these rights accessible to all taxpayers. Since the taxpayer rights declarations does not have an impact at the law level, its enforcement is limited.

The declaration owned by France is a declaration that includes the rights and responsibilities of both the administration and taxpayers. It is noteworthy that the French taxpayer rights declaration has been prepared in a comprehensive and detailed manner. Germany, on the other hand, has regulated the taxpayer rights under the tax law instead of the declaration. The classical rights, there are in many countries such as the right to petition and the right to tax privacy, are also found in Germany. Japan is also one of the developed countries that engages in various studies on taxpayer rights. However, due to the lack of clear provisions stating taxpayer rights in Japanese legislation, we cannot see the taxpayer rights collectively. The Japanese tax administration has also not issued a declaration on taxpayer rights. However, taxpayers are informed through the reports published by NTA.

The England has protected the rights of taxpayers through the taxpayer declaration made compatible with the conditions of the time. The USA, on the other hand, is one of the countries that regulate the taxpayer rights by law. IRS has made regulations with both at the level of declaration and law from past to the present. IRS sees it as an important task to assist taxpayers through the phase of fulfilling their tax liability. In addition, it is aimed to find quick solutions with the help of the administration of the taxpayer's attorney regarding to the problems of the taxpayers. Although the Australian revenue administration has begun late addressing the issues of taxpayer rights, it has made increasingly progress in this process. The practice of tax ombudsman is one of the successful examples regarding to demonstrating of the importance of taxpayer rights.

The taxpayer rights declarations can be also evaluated in terms of its own various characteristics that they have. While both rights and duties of taxpayers have been considered in taxpayer rights declaration of England, the USA has addressed only the rights. While Australia has explained the rights and duties in detail, there isn't such a detailed arrangement in Japan. While the USA and Germany regulated their taxpayer rights at the level of a law, England, Australia and France have preferred to regulate them with declarations. When country practices are examined, it is noticeable that there is no single standard declaration that can be applicable in each country. When all these issues are evaluated together, we think that it will be in favor of taxpayers to regulate taxpayer rights by law. When the sanction power of law and declaration is compared, it can be said that the sanction power of the law in terms of taxpayer rights will be much higher.

When looking at practices of developed democratic country, it is noticeable that they attach the necessary importance to taxpayer rights. It has been seen that developing countries have also tried to integrate taxpayer rights into their own systems, based on practices of developed countries. Having been supported with sanctions both of taxpayer 
rights and duties is an important subject. Having been demonstrated the necessary sensitivity to taxpayer rights will be able to affect taxpayers' voluntary compliance and tax awareness positively. Thus, it will be able to be experienced a positive effect on the subject of tax-related transactions between the taxpayer and revenue administration. 
Eskişehir Osmangazi Üniversitesi IißBF Dergisi 